\title{
Contribution of the Chemistry Institutes to the Early Development of Stereochemistry
}

\author{
Kurt Hermann§
}

\begin{abstract}
This article is a translation from German of a paper submitted by Kurt Hermann to the University of Zurich Prize committee in 1968, with additional editing by Jay Siegel. It covers a survey of the historical contributions of faculty at $\mathrm{UZH}$ to the fundamental development of stereochemistry. It is appropriate in light of the $90^{\text {th }}$ birthday of Andre Dreiding, pioneer of stereochemistry and founder of the Buergenstock stereochemistry meeting, that we reflect on the chain of historical events responsible for UZH's leading role in this important molecular discipline.
\end{abstract}

Keywords: Dreiding, A. · Karrer, P. · Stereochemistry · UZH Chemistry Institutes · Werner, A.

Wäre die Natur in ihren leblosen Anfängen nicht so gründlich stereometrisch, wie wollte sie zuletzt zum unberechenbaren und unermesslichen Leben gelangen?

J. W. von Goethe

\section{Introduction}

The term 'stereochemistry' was introduced in 1888 by V. Meyer. ${ }^{[1]}$ The concept of the spatial arrangement of atoms in chemical compounds is, however, older. It will probably never be possible to determine with certainty who first expressed the idea that molecules possess a three-dimensional shape. It may have been W. H. Wollaston, who postulated as early as 1808 , that not only the composition of a compound but also the spatial position of individual atoms in that compound must be determined

Correspondence: Prof. Dr. J. S. Siegel

Institute of Organic Chemistry

University of Zurich

Winterthurerstrasse 190

$\mathrm{CH}-8057$ Zürich

Tel.: +4144635 4281

Fax: +41446356888

E-mail: jss@oci.uzh.ch

\$Translated by Gillian Harvey to fully explain the chemical properties. He even discussed the possibility that compounds of the general formula $\mathrm{AB}_{4}$ could exist as regular tetrahedra. ${ }^{[2]}$ This was no more than speculation at that time. However, when in 1874 van't Hoff[3] and Le Bel ${ }^{[4]}$ postulated independently the tetrahedral arrangement of substituents around a fourcoordinated carbon atom, they did so from a desire to explain the discoveries of other scientists that could no longer be rationalised using only two-dimensional structural chemistry concepts.

Today it is possible to determine the geometric relationships between individual atoms extremely accurately using spectroscopic methods. In many ways, stereochemistry has developed into an exact science and an important aspect of all chemistry disciplines.

It is not the aim or the purpose of this article to present an exhaustive account of the stereochemistry research at the Chemistry Institutes of the University of Zurich. The main emphasis is on a description of the fundamental contribution of A. Werner (1866-1919) to the stereochemistry of inorganic complexes. The other, much shorter sections on the research of J. Wislicenus (1835-1902), P. Pfeiffer (1875-1951), P. Karrer (1889-1971) and A. S. Dreiding (1919) illustrate that research on stereochemistry has always been pursued at the Chemistry Institutes of the University of Zurich.

\section{Johannes Wislicenus}

\section{The Different Modifications of}

\section{Lactic Acid}

In Innsbruck ${ }^{[5]}$ and Zurich, ${ }^{[6]}$ Wislicenus reported his work on homologues of lactic acid (hydroxypropanoic acids). $\mathrm{He}$ differentiated between the following modifications (Fig. 1):

i) 3-Hydroxypropanoic acid (1) - synthesized by Wislicenus in 1863 from 2-chloroethanol; [7]

ii) 2-Hydroxypropanoic acid (2) - synthesized by Wislicenus in 1863 from acetaldehyde; [7]

iii) 2-Hydroxypropanoic acid (3) - $d$-lactic acid.

The 2-hydroxypropanoic acids are structurally identical. Wislicenus postulated that only by assuming different spatial arrangements of the atoms in the two compounds, was it possible to differentiate between the two isomers. (Wislicenus summarized his arguments in $1873^{[8]}$.)

This theory was taken up by van't Hoff in 1874. In a short article he proposed the tetrahedral arrangement of the substituents of the carbon atoms. ${ }^{[3]}$ With this theory, generally accepted today, it became possible to explain the difference between the two 2-hydroxypropanoic acids: 2-hydroxypropanoic acid (2) (fermentation lactic acid) is the $1: 1$ mixture of $d$ - and $l$-isomers, lactic acid $\mathbf{3}$ is the pure $d$-isomer (Fig. 1).

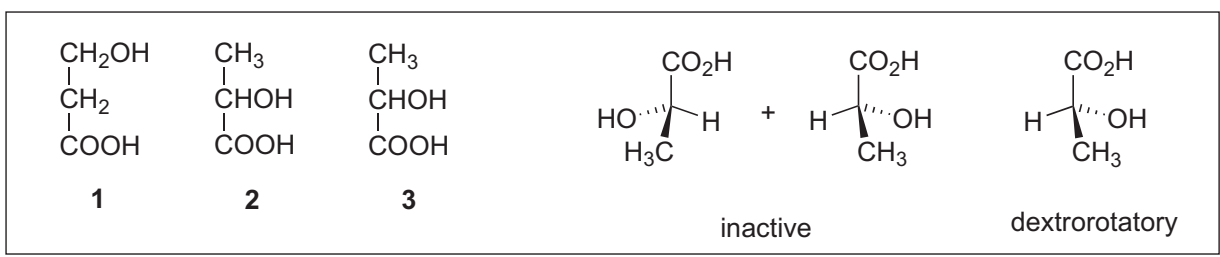

Fig. 1. Isomers of lactic acid. 
It is generally recognized that the research carried out by Wislicenus in Zurich on the different modifications of lactic acid made an important contribution to the development of stereochemistry. Although Wislicenus did not make the decisive step towards the new theory, his research encouraged van't Hoff to take up the problem and ultimately led him to become the founder of the stereochemistry of organic chemistry.

Also after he left Zurich, Wislicenus continued to work on stereochemistry problems. The translation of van't Hoff's work by F. Herrmann, at the suggestion of Wislicenus, did much to gain acknowledgement for his theories, which had not attracted much attention initially. ${ }^{[9]}$ The article by Wislicenus on the stereochemistry of ethylene derivatives also made an important contribution to the subject. ${ }^{[10]}$

\section{Alfred Werner}

The most important contributions from the University of Zurich to the development of stereochemistry come undoubtedly from Werner and his coworkers. Before this work is described, the situation before Werner's work, the coordination theory itself, and one of the most important analytical methods relevant to stereochemistry are discussed.

\section{The Theory of Blomstrand and Jørgensen}

This theory is also known as the ammonia theory. According to C. W. Blomstrand ammonia molecules in metal ammonia salts can form chains in the same way as methylene groups in organic compounds. Halide ions or other acidic groups are connected either directly or via the ammonia chain to the metal atom. ${ }^{[11,12]}$ Tetrammine platinum(II) chloride (4) is given as an example in Fig. 2. A similar situation is found for the metal ammonia salts of cobalt, iridium, rhodium, etc.

In 1890 S. M. Jørgensen showed that the complexes formed from cobalt(III) chloride and ammonia were monomolecular and not bimolecularaspostulatedbyBlomstrand. [13] As early as 1883, Jørgensen had discovered that in cobalt ammonia salts with the composition $\left(\mathrm{CoCl}_{3}\left(\mathrm{NH}_{3}\right)_{4}\right)_{\mathrm{n}}$ ( $n$ assumed to be 2 , up to 1890 ) only a third of the chlorine atoms had ionic character. ${ }^{[14]}$ His explanation was that the 'masked' chlorine is directly connected to the cobalt atom whereas the chlorine with ionic character was indirectly connected to the cobalt (Fig. 2). Jørgensen remained a staunch life-long believer in his theory, which was based on the strict rules of classical valence theory by A. S. Couper ${ }^{[15]}$ and A. Kekulé. [16] However, his careful preparative and ana-

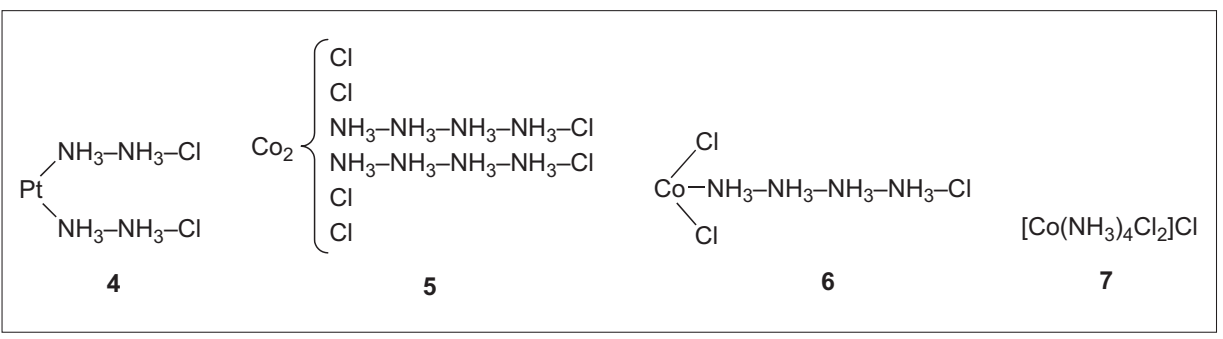

Fig. 2.

lytical work contributed a great deal to the development of Werner's coordination theory.

\section{Werner's 'Contribution to the The- ory of Affinity and Valence'}

The above-mentioned theory of constant, indivisible, individual valence ${ }^{[15,16]}$ was eminently suited to describe the structure and stereochemical properties of organic compounds but failed in other cases. In his article published in 1891, Werner presented his belief that atoms are spheres that exert an attractive affinity equally in all directions. ${ }^{[17]} \mathrm{He}$ wrote: "Valence means an empirically determined numerical proportion (of atoms) in which the atoms are connected to each other, independent of the valence unit". The hydrogen atoms in methane are tetrahedrally arranged around the carbon atom because this arrangement ensures the greatest possible exchange between the affinities of the hydrogen atoms and the carbon atoms. The application of these principles to the metal ammonia salts enabled Werner to postulate his coordination theory in 1893.

\section{Coordination Theory}

In 1893, shortly before he was elected successor to V. Merz (1839-1904), Werner published his article 'Contribution to the Structure of Inorganic Compounds'. [18] Werner concentrated principally on the metal ammonia salts and their derivatives. He recognized that the many 'molecular compounds' or 'compounds of higher order', as these complexes were also called at the time, could not be explained by the constant valence theory. He created the term 'coordination number'. The coordination number describes the maximum number of ions or molecules that can be connected directly to the central atom (or central ion) to form the 'primary sphere'. The number of coordination positions depends essentially on the type of central atom and spatial factors, but not on the valence of the central atom. Cobalt(III) has the coordination number 6 in all its complexes. Therefore, compound 7 (dichlorotetrammine cobalt(III) chloride, Fig. 2) has the formula: $\left[\mathrm{Co}\left(\mathrm{NH}_{3}\right)_{4} \mathrm{Cl}_{2}\right] \mathrm{Cl}$. The group of atoms in square brackets make up the primary sphere. The chlorine atom outside the parentheses is not directly connected to the cobalt: in contrast to the other two chlorine atoms, it possesses ionic character. Werner divided the complexes into two main groups: complexes with the coordination number 6 and those with the coordination number 4 :

$$
\begin{aligned}
& {\left[\mathrm{ML}_{6}\right]: \mathrm{M}=\mathrm{Co}^{(\mathrm{III})}, \mathrm{Pt}^{(\mathrm{IV})}, \mathrm{Ir}^{(\mathrm{III})}, \mathrm{Cr}^{(\mathrm{III})}, \mathrm{Fe}^{(\mathrm{III})},} \\
& \text { etc. } \\
& {\left[\mathrm{ML}_{4}\right]: \mathrm{M}=\mathrm{Pt}^{(\mathrm{III})}, \mathrm{Pd}^{(\mathrm{II})}, \text { etc. }} \\
& \left(\mathrm{L}=\mathrm{NH}_{3}, \mathrm{H}_{2} \mathrm{O}, \mathrm{Cl}^{-}, \mathrm{Br}^{-}, \mathrm{CN}^{-}, \mathrm{SCN}^{-}\right. \\
& \left.\mathrm{NO}_{2}^{-}, \text {etc. }\right)
\end{aligned}
$$

Further aspects of the coordination theory will be discussed, where appropriate, during the description of Werner's research.

\section{Conductivity Measurements}

Knowledge of the exact composition of complexes was required to provide experimental support for the coordination theory and Werner's stereochemistry theories. The methods available in 1890 were not always able to provide this information. Correlations between the composition of complex salts and the electrical conductivity in aqueous solution, as determined by Werner and Miolati, ${ }^{[19-21]}$ provided a real improvement in the analytical methods in complex chemistry because the number of ions in the individual complexes could be established. The demonstration that the complexes $\left[\mathrm{Pt}\left(\mathrm{NH}_{3}\right)_{2} \mathrm{Cl}_{4}\right]$ and $\left[\mathrm{Co}\left(\mathrm{NH}_{3}\right)_{3}\left(\mathrm{NO}_{2}\right)_{3}\right]$ had no electrical conductivity was particularly significant since this had been predicted to be the case by the coordination theory (Fig. 3).

\section{General Observations on the Stereochemistry of Complexes with the Coordination Number 6}

In principle there are an infinite number of possible arrangements of ligands around a central atom. Werner ${ }^{[18]}$ excluded with high probability all unsymmetrical arrangements, since no isomers of complexes with the general formula $\left[\mathrm{MA}_{6}\right] \mathrm{X}_{\mathrm{n}}$ and $\left[\mathrm{MA}_{5} \mathrm{~B}\right] \mathrm{X}_{\mathrm{n}}$ had ever been observed. (An exception are complexes where $\mathrm{B}=\mathrm{NO}_{2}^{-}$, where either the nitrogen or the oxygen can coordinate to the central atom, i.e. salt or 


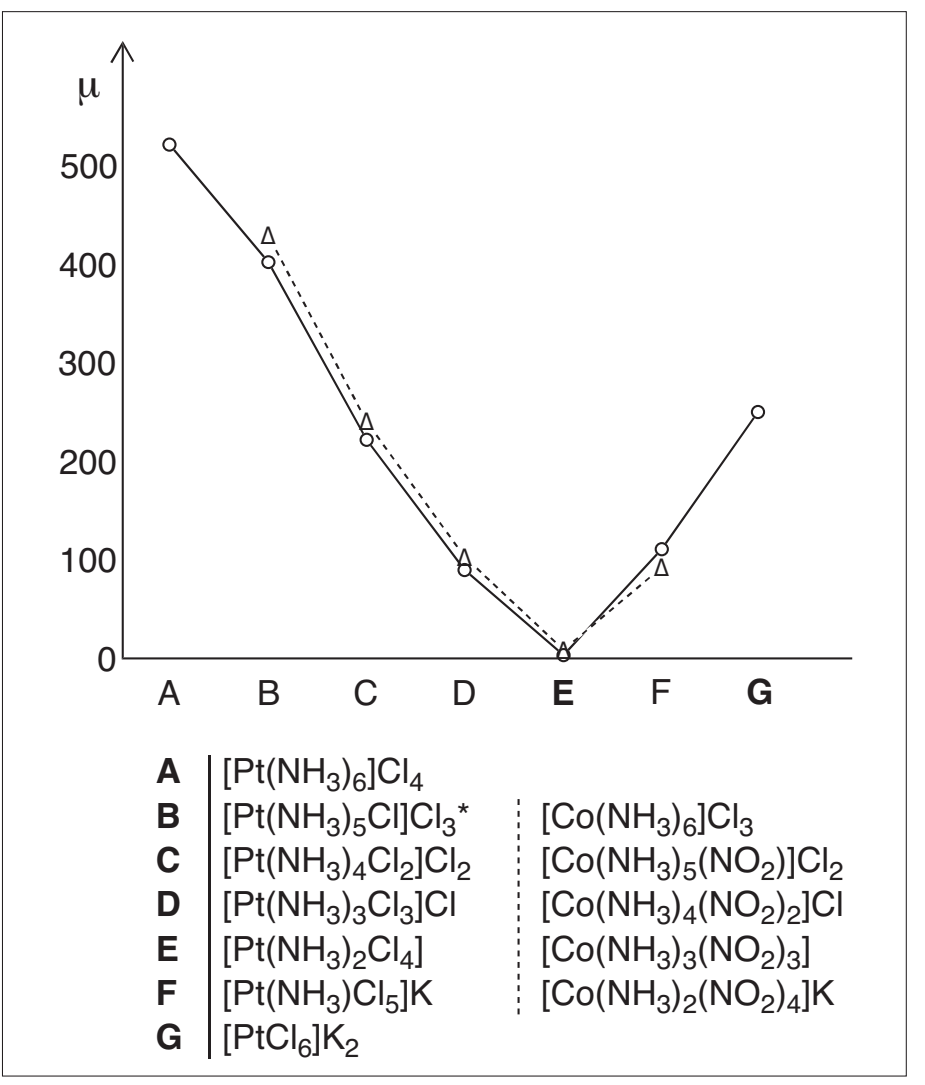

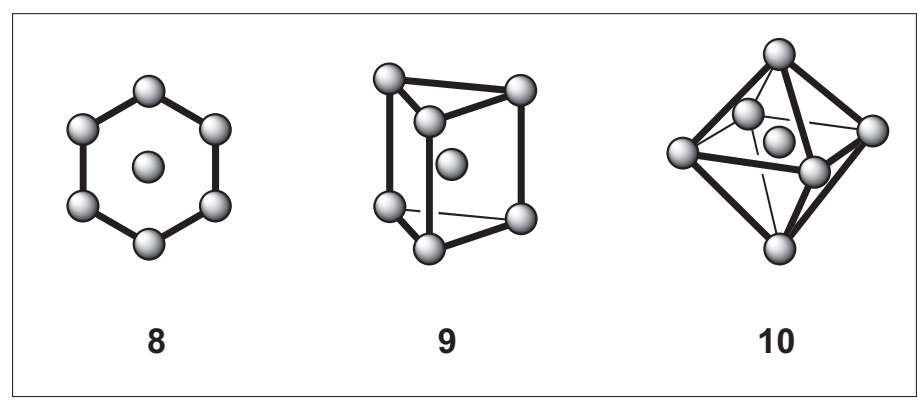

Fig. 4. Possible arrangements of complexes with coordination number 6.

Fig. 3. Molar conductivity of $0.1 \mathrm{M}$ aqueous solutions. *This value was measured by Tschugaeff and Wladimiroff. ${ }^{[22]}$ fumaric acid because ring closure cannot occur in the trans compound for steric reasons. Werner assumed that bidentate ligands occupy neighbouring coordination sites. This applies in particular for geometric reasons to carbonato ligands (Fig. 7). ${ }^{[23]}$ The existence of the strained four-ring system on the carbonato complexes had been frequently contested. In 1962 their existence was finally and unambiguously established by an X-ray study of carbonatotetrammine cobalt(III) bromide. ${ }^{[24]}$ structural isomerism). Therefore Werner took only the planar (8), prismatic (9) and octahedral arrangements (10) into account (Fig. 4).

Werner decided against the first two possibilities because only a maximum of two isomeric series had been observed for all known compounds with the formula $\left[\mathrm{MA}_{4} \mathrm{~B}_{2}\right] \mathrm{X}_{\mathrm{n}}$; a planar or prismatic arrangement would have given rise to three isomers (Fig. 5). Therefore the ligands in transition metal complexes with the coordination number 6 should be arranged octahedrally around the central atom.

The evidence for this was relatively weak at that time and Werner took almost 20 years to establish finally his theory. Many experiments at that time were aimed at solving stereochemical problems. These experiments are described in the following section.

\section{Cis-Trans Isomerism Nomenclature}

The two isomeric series of complexes with the general formula $\left[\mathrm{MA}_{4} \mathrm{~B}_{2}\right] \mathrm{X}_{\mathrm{n}}$ often differ in colour, solubility, crystal morphology etc. Werner ${ }^{[23]}$ named them cis and trans in analogy to the isomeric ethene compounds (Fig. 6).

\section{Determination of Configuration and Stereospecific Synthesis}

Maleic anhydride (13, Scheme 1) is produced when maleic acid (12) is heated; the same product is obtained at higher temperature by rearrangement of

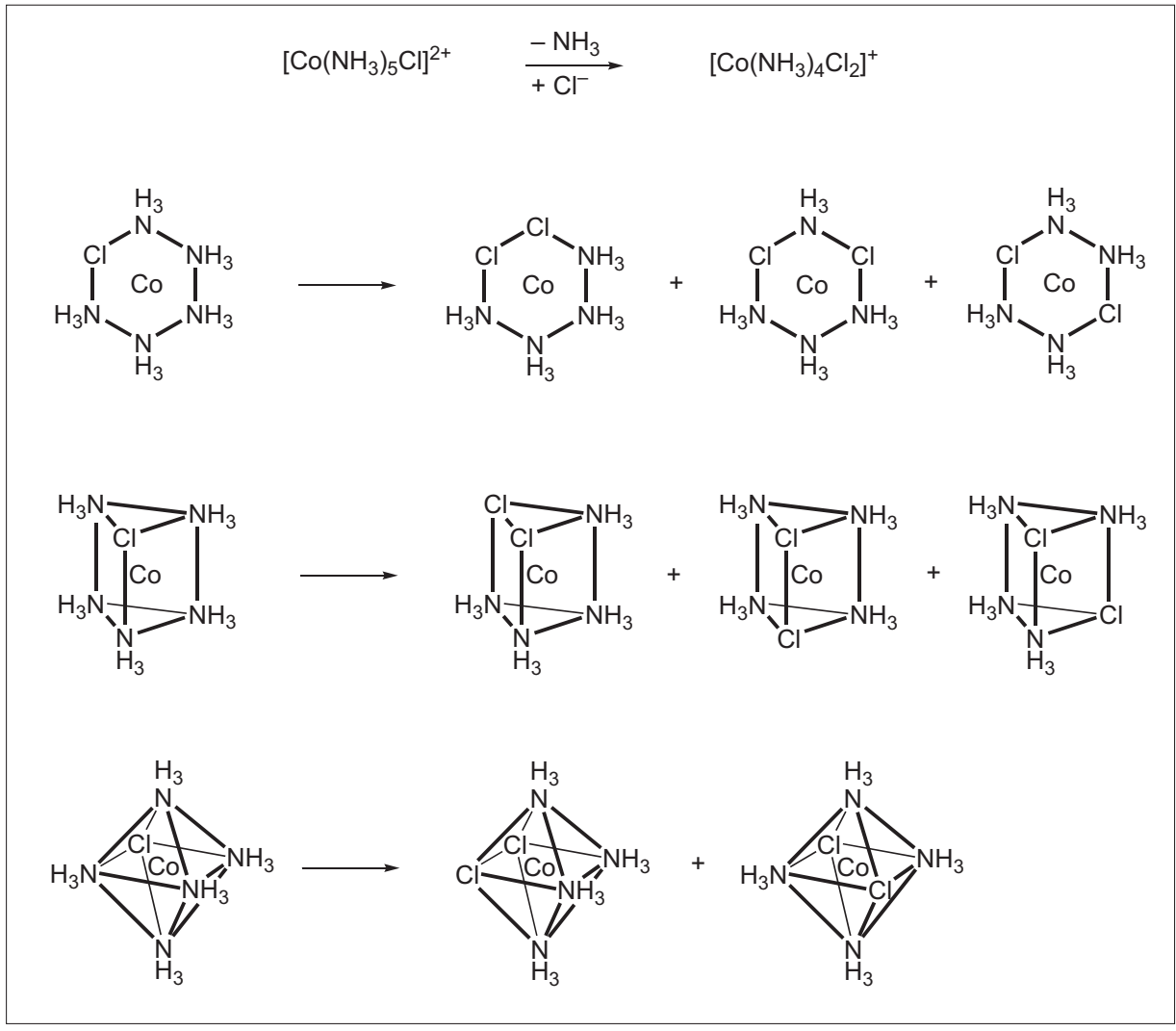

Fig. 5. Possible isomers for complex ions of the type $\left[\mathrm{MA}_{4} \mathrm{~B}_{2}\right]^{+}$using $\left[\mathrm{Co}\left(\mathrm{NH}_{3}\right)_{4} \mathrm{Cl}_{2}\right]^{+}$as an example.

${ }_{A}$




\section{$11 \underset{-\mathrm{H}_{2} \mathrm{O}}{\stackrel{275^{\circ} \mathrm{C}}{\longrightarrow}}$ \\ 13 \\ Scheme 1}

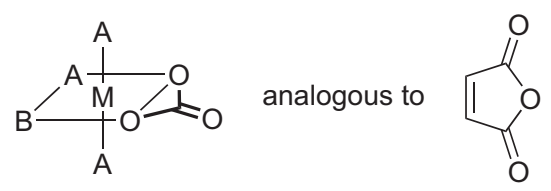

Fig. 7.

Werner did not share these doubts because he used these complexes for the determination of configuration. He had to assume that complexes that are generated by the substitution of carbonato ligands or that can be converted to carbonato complexes would have cis configuration (Scheme 2).

An example: Two dinitrotetrammine cobalt(III) salt series were known: the brown flavo- and the yellow croceo salts. In the reaction of carbonatotetrammine cobalt(III) salts with sodium nitrite, Jørgensen obtained only the flavo series.[25] Werner concluded that the flavo compounds had cis configuration, the croceo compounds trans.

A further method used by Werner to prepare cis complexes was the cleavage of binuclear complexes bridged by hydroxyl groups. [26] Stereochemical considerations required that the two hydroxyl ligands in the reactant (15) and the two chloro or aquo ligands in the products $\mathbf{1 6}$ and $\mathbf{1 7}$ should be cis to one another (Scheme 3).

This line of reasoning was not incontestable. Werner observed rearrangements in many reactions.[27] In 1889 Jørgensen had established that transdichlorobis(ethylenediamine) cobalt(III) chloride (18) could be transformed to the cis compound (16). ${ }^{[28]}$ Under suitable conditions the reverse reaction could even be performed (Scheme 4).

Such rearrangements are clearly highly undesirable in substitution reactions unless it is possible to predict their occurrence. Werner recognized this and researched extensively on the subject. ${ }^{[27,29]}$ The result was a theory on substitution reaction pathways that are today known as reaction mechanisms.

\section{Reaction Mechanisms}

Werner ${ }^{[27,29]}$ proposed the following pathway for substitution in coordinatively saturated compounds. An interaction occurs between the central atom and the re-

Scheme 3.

Scheme 5.

20

Scheme 6. actant in the second coordination sphere. This interaction is not equally strong in all directions. The reagent enters the primary sphere preferably at the position with the strongest interaction, at the same time displacing the most weakly bound ligand from the primary sphere. Werner ${ }^{[29]}$ illustrated this mechanism with the reaction between trans-dichloro-bis(ethylenediamine) cobalt(III) chloride (18) and ammonia (Scheme 5).

Theoretically direct attack of the incoming ligand on the coordination site of the leaving group is also possible. In such cases configuration is retained. Scheme 6 shows how Werner would probably have formulated such a reaction.

In this way, Werner was able to explain experimental observations, but he could not predict the reaction pathway. His attempt to discover patterns (for example exclusive or preferred formation of the most favoured product) based on a large number
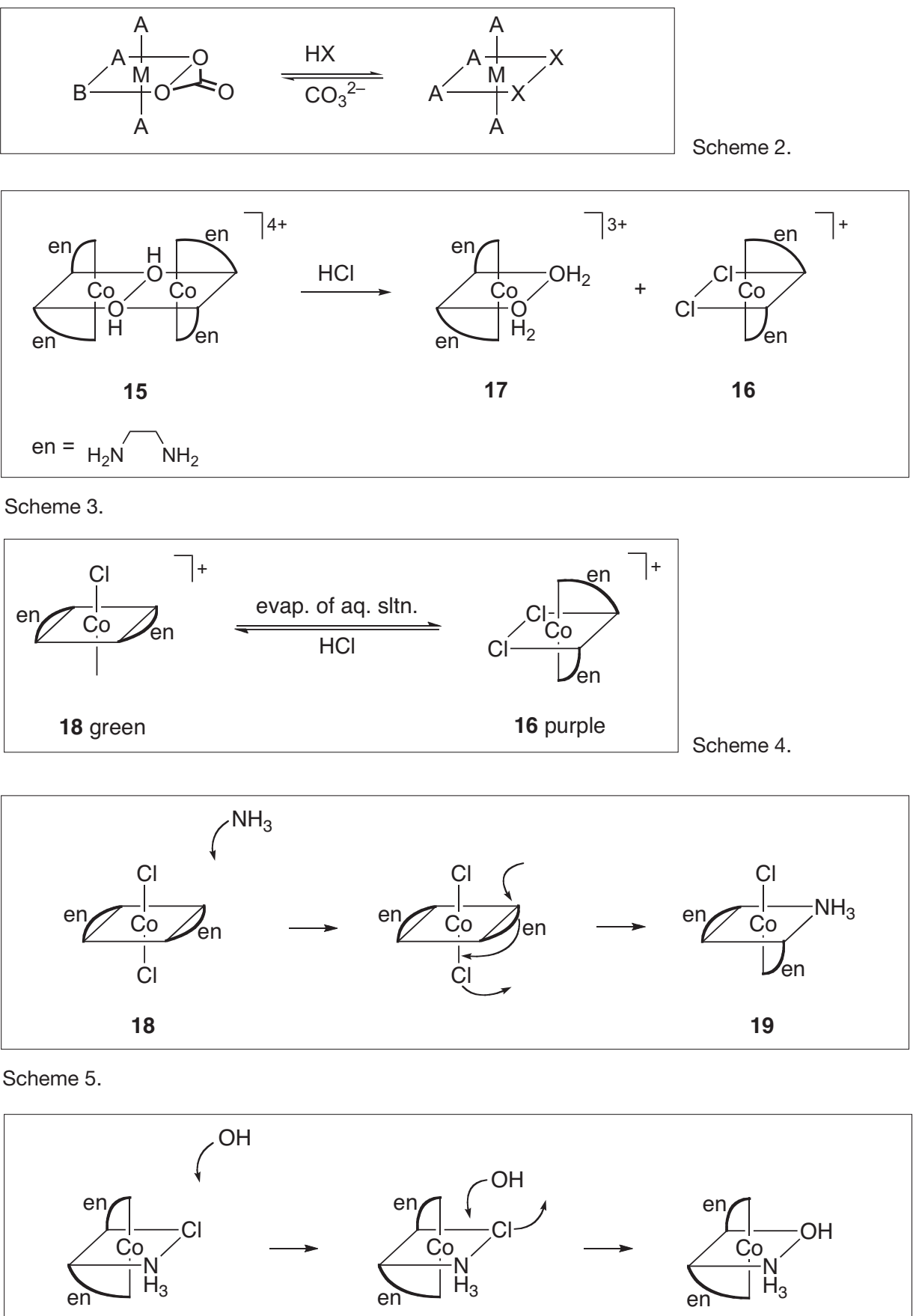
of reactions of complexes with the general formula [Coen $\left.{ }_{2} \mathrm{XY}\right] \mathrm{Z}_{\mathrm{n}}$ failed. ${ }^{[29]}$ This is not surprising since up to 1956 methods to prepare trans compounds, for example, were purely empirical. [30]

Werner's theory of the Walden inversion developed from the above-mentioned theory of rearrangement in substitution reactions of coordinatively saturated complex compounds. Werner proposed[27] the following reaction sequence for the reaction of an alcohol with a hydrogen acid $\mathrm{HX}$ :

$$
\begin{array}{ll}
\mathrm{R}_{3} \mathrm{COH}+\mathrm{HX} & \rightarrow\left[\mathrm{R}_{3} \mathrm{COH}_{2}\right] \mathrm{X} \\
{\left[\mathrm{R}_{3} \mathrm{COH}_{2}\right] \mathrm{X}} & \rightarrow \mathrm{R}_{3} \mathrm{CX}+\mathrm{H}_{2} \mathrm{O}
\end{array}
$$

The site of attack of the nucleophile determines whether the substitution occurs with the conservation of the configuration or with Walden inversion (Scheme 7).

Similar thoughts were expressed at the same time by E. Fischer ${ }^{[31]}$ and P. Pfeiffer. ${ }^{[32]}$ Werner's analysis of the Walden inversion is very similar to the mechanism accepted today. It provides a convincing explanation for the inversion; but, it should also be noted that it is not possible to predict under which conditions it will occur. Our current understanding of substitution reactions with conservation of configuration is quite different from that of Werner's.

\section{Optically Active Compounds}

Werner obtained the most convincing evidence for the octahedral configuration of complexes with the coordination number 6 with racemate resolutions published from 1911 onwards. As early as 1901 Werner and Vilmos ${ }^{[33]}$ discussed the possibility of mirror-image isomers in oxalatobis(ethylenediamine) cobalt(III) salts (22) (Fig. 8). They compared this type of stereoisomerism with that in spiro compounds (23).

Werner and Vilmos hoped that the crystals of the complex salts 22 would show hemihedrism and could be mechanically separated into their enantiomers. Pasteur used this method ${ }^{[34]}$ for the first racemic resolution, the separation of sodium ammonium salts of $d, l$-tartaric acid. Werner and Vilmos were, however, unsuccessful.

\section{The First Racemic Resolution}

This succeeded in 1911 with complex salts of the general formula $\left[\mathrm{Co}(\mathrm{en})_{2} \mathrm{NH}_{3} \mathrm{X}\right)$ $\mathrm{Y}_{2}(\mathbf{2 4})(\mathrm{X}, \mathrm{Y}=\mathrm{Br}, \mathrm{Cl})$. Werner ${ }^{[35]}$ used a well-known technique from organic chemistry:[34] A racemate $d, l-\mathrm{A}$ is reacted with $d$-B, to produce diastereoisomeric salts of composition $d$-A, $d$-B and $l$-A, $d$-B which differ in their physical properties and can frequently be separated by fractional crystallization. The first experiment made use of silver salts of $d$ - $\alpha$-bromocamphor- $\pi$ sulfonic acid (d-25) (Scheme 8).
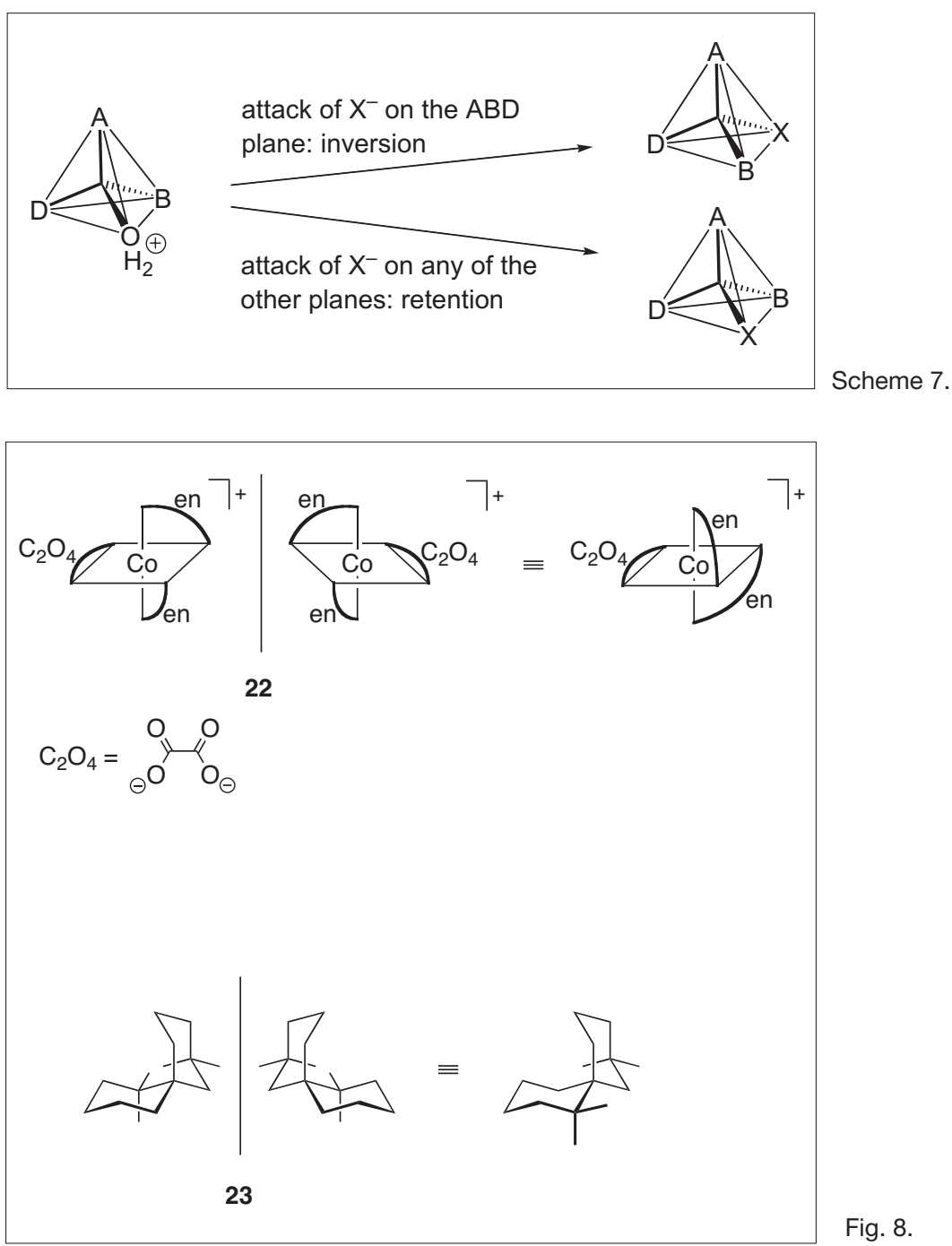

Fig. 8.

To Werner's surprise, the enantiomers racemised only very slowly in aqueous solution. Their molar rotation at $656.3 \mathrm{~nm}$ (Fraunhofer line C) was

$[\mathrm{M}]_{\mathrm{C}}=+172.34^{\circ},-168.54^{\circ}$ for cis-

$\left[\mathrm{Co}(\mathrm{en}) \mathrm{NH}_{3} \mathrm{Cl}\right] \mathrm{Br}_{2}$

$[\mathrm{M}]_{\mathrm{C}}=+201.65^{\circ},-196.2^{\circ}$ for cis-

$\left[\mathrm{Co}(\mathrm{en})_{2} \mathrm{NH}_{3} \mathrm{Br}\right] \mathrm{Br}_{2}$

Therefore, Werner had proved that (coordination) complexes could also be optically active. At the same time he had found a good method to differentiate between cis and trans compounds: only the cis compounds could be resolved into their enantiomers.

Publications on further successful resolutions rapidly followed.[36-41] Three interesting examples are described here.

\section{Resolution of $\left[\mathrm{Co}(\mathrm{en})_{3}\right] X_{3}(26)$}

Although all six coordination sites are occupied by structurally identical groups, these compounds are optically active $\left([\mathrm{M}]_{\mathrm{D}}= \pm 602^{\circ}\right.$ for $\left.\mathrm{X}=\mathrm{Br}\right)$. This is due to the chiral arrangement of the substituents (Fig. 9). [39]

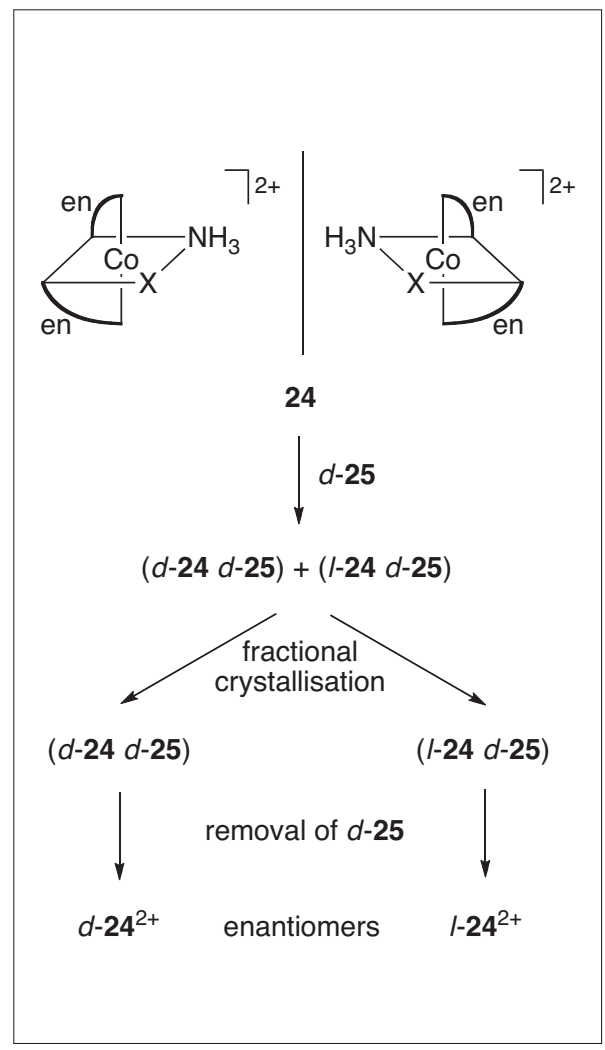

Scheme 8. 


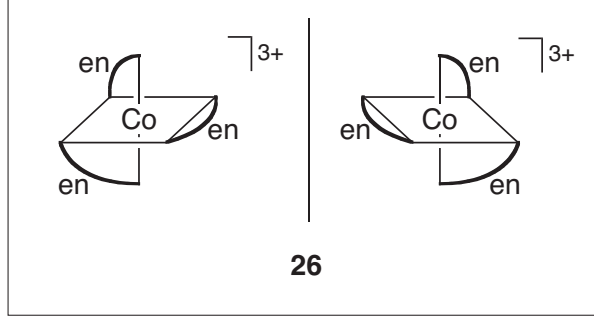

Fig. 9.

\section{Inorganic meso-Compounds}

Earlier Werner had repeatedly investigated polynuclear complexes. In the bis(ethylenediamine) cobalt(III)- $\mu$-amido$\mu$-nitrobis(ethylenediamine) cobalt (III) salts (27) he discovered isomerism analogous to that observed for tartaric acid (28) (Fig. 10). ${ }^{40]}$ The meso-compounds (meso-28) could not be resolved into enantiomers by any of the known methods. In contrast the two enantiomers $d$ - and $l-27$ could be obtained from the other series using $d$ - $\alpha$-bromocamphor- $\pi$-sulphonic acid (25). After prolonged heating in water the enantiomers lost their optical activity. Werner proposed an intramolecular rearrangement to form the meso-compound (Scheme 9).

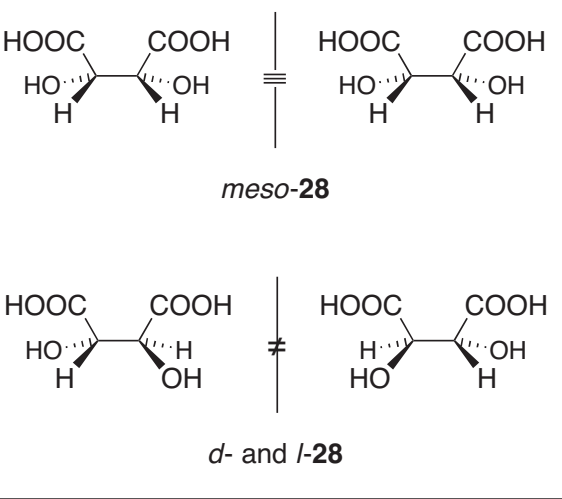

Fig. 10.

An interesting aspect of the general coordination theory is mentioned briefly: Werner originally differentiated between primary and secondary valences of the central atom. Primary valences could only be neutralised by negative ligands or ions in the second sphere; secondary valences in contrast by any ligands. If there really were fundamental differences between the two types of valences, this would mean that meso-27 would be a racemic mixture and therefore could be resolved into enan-

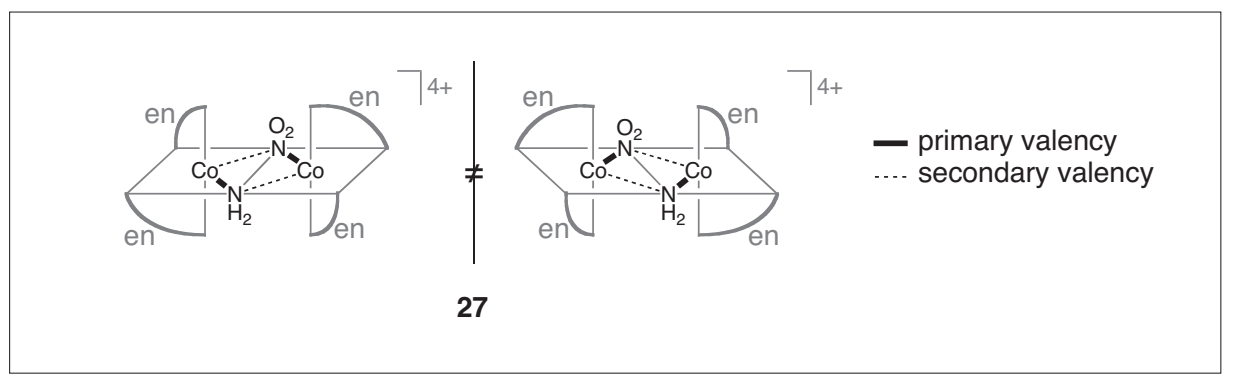

Fig. 11.
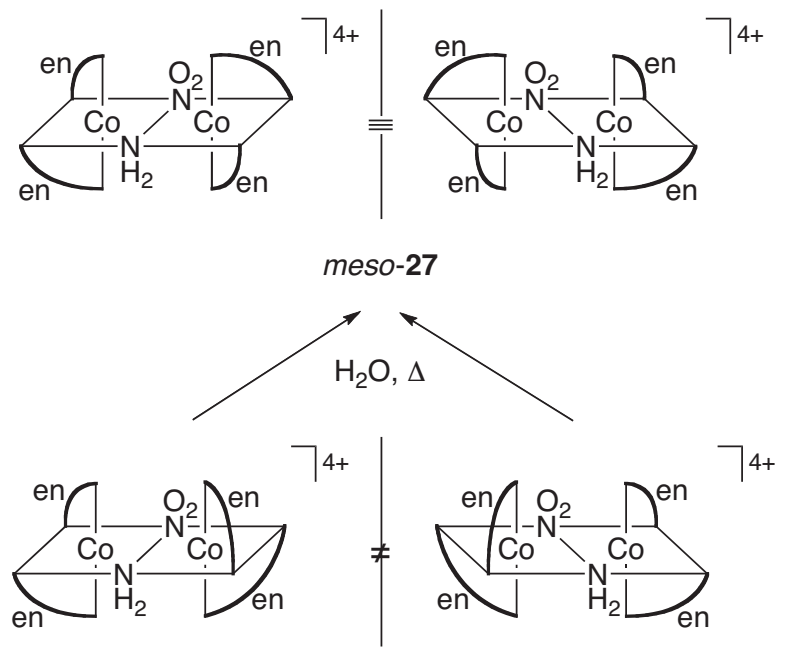

$d$ - and $1-27$

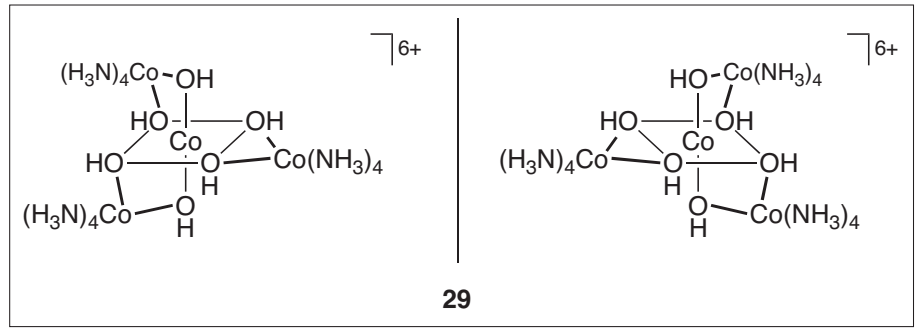

Fig. 12.

tiomers (Fig. 11). After his unsuccessful resolution attempts, Werner abandoned the differentiation into primary and secondary valences that he had anyway previously considered to be unsatisfactory. ${ }^{[42]}$ (For this reason, we have never used such a differentiation).

\section{Optically Active Cobalt Complexes without Carbon-containing Ligands}

The only objection to Werner's octahedral theory with respect to the abovementioned results could have been that all the investigated enantiomers contained carbon (in ethylenediamine). Therefore the successful enantiomer resolution of the four-centre carbon-free compound 29 (Fig. 12) in 1914 was all the more significant. ${ }^{[41]}$

\section{Optically Active Complexes without Cobalt}

The proof provided by Werner and his coworkers that complexes of chromium, iron, rhodium, platinum and iridium could also display optical activity (Table 1) was also important for the general acceptance of the octahedral theory.

Only the iridium compounds were produced by a chemist other than Werner: in 1914 M. Délepine ${ }^{[48]}$ published the successful racemic resolution of $\left[\operatorname{Ir}\left(\mathrm{C}_{2} \mathrm{O}_{4}\right)_{3}\right)$ $\mathrm{K}_{3} .2 \mathrm{H}_{2} \mathrm{O}$.

\section{Resolution with Optically Active Complexes}

The first resolution of racemic complexes was performed by Werner with the help of various optically active organic compounds. But with the first resolution of the racemic sym-dimethylsuccinic acid (30) Werner utilized a different method. ${ }^{[49]}$ As reagent he used the $d$ tris(ethylenediamine) cobalt(III) ion. The isomer that melted at $127{ }^{\circ} \mathrm{C}$ was shown to be a racemic mixture, with enantiomers having a specific rotation of $\pm 8^{\circ}$, whereas the isomer that melted at $195{ }^{\circ} \mathrm{C}$ could not be resolved (meso-compound). There is no graphic representation of this reaction shown here since the same principles as in the isomers of tartaric acids (28) are apparent. These methods were further developed more recently by Dwyer and coworkers, in particular.[50] 
Table 1.

$\begin{array}{llll}\text { Complexes } & {[\mathrm{M}]} & \text { Light source } & \text { Ref. } \\ {\left[\mathrm{Cr}(\text { en })_{2} \mathrm{Cl}_{2}\right] \mathrm{Cl}} & \pm 415.1^{\circ} & \mathrm{Na}_{\mathrm{D}} & \text { Werner } \mathrm{r}^{[43]} \\ {\left[\mathrm{Fe}(\text { dipy })_{3}\right] \mathrm{Br}_{2} \cdot \mathrm{H}_{2} \mathrm{O}} & -4117.8^{\circ} & \mathrm{Nernst} \text { lamp } & \text { Werner } \\ \left.\left[\mathrm{Rh}(\mathrm{en})_{3}\right]_{3}\right]_{34]} & \pm 323^{\circ} & \mathrm{Na}_{\mathrm{D}} & \text { Werner } \\ {\left[\mathrm{Pt}(\mathrm{en})_{3}\right](\mathrm{SCN})_{4}} & \pm 510.3^{\circ} & \mathrm{Na}_{\mathrm{D}} & \text { Werner } \\ {\left[\mathrm{Ir}(\mathrm{en})_{3}\right]\left(\mathrm{NO}_{3}\right)_{3}} & \pm 320^{\circ} & \mathrm{Na}_{\mathrm{D}} & \text { Werner and Smirnoff }\end{array}$

Table 2.

\begin{tabular}{|c|c|c|}
\hline Reactant & Reagent & Product \\
\hline I-[Co(en) $\left.)_{2} \mathrm{Cl}(\mathrm{NCS})\right]^{+}$ & $\mathrm{NaNO}_{2}$ & $d-\left[\mathrm{Co}(\mathrm{en})_{2} \mathrm{NO}_{2}(\mathrm{NCS})\right]^{+}$ \\
\hline$d$-[Co(en) $\left.{ }_{2} \mathrm{CINO}_{2}\right]^{+}$ & $\mathrm{KSCN}$ & $d$-[Co(en) $\left.)_{2} \mathrm{NO}_{2}(\mathrm{NCS})\right]^{+}$ \\
\hline$d-\left[\mathrm{Co}(\mathrm{en})_{2} \mathrm{CINO}_{2}\right]^{+}$ & $\mathrm{NaNO}_{2}$ & $d-\left[\mathrm{Co}(\mathrm{en})_{2}\left(\mathrm{NO}_{2}\right)_{2}\right]^{+}$ \\
\hline$I-\left[\mathrm{Co}(\mathrm{en})_{2} \mathrm{Cl}_{2}\right]^{+}$ & $\mathrm{K}_{2} \mathrm{CO}_{3}$ & $d-\left[\mathrm{Co}(\mathrm{en})_{2} \mathrm{CO}_{3}\right]^{+}$ \\
\hline$d-\left[\mathrm{Co}(\mathrm{en})_{2} \mathrm{Cl}_{2}\right]^{+}$ & $\mathrm{K}_{2} \mathrm{C}_{2} \mathrm{O}_{4}$ & $I-\left[\mathrm{Co}(\mathrm{en})_{2} \mathrm{C}_{2} \mathrm{O}_{4}\right]^{+}$ \\
\hline
\end{tabular}

\section{Comparison of Configuration}

In 1912 Werner presented the principle that those stereoisomers that form the least soluble salts with the same optically active organic acid will have the same configuration. ${ }^{[45]}$ With the application of this principle Werner concluded that the following complex ions had the same configuration: $d$-[Co(en $\left.)_{3}\right]^{3+}, d$ $\left[\mathrm{Cr}(\text { en })_{3}\right]^{3+}, \quad l-\left[\mathrm{Rh}(\text { en })_{3}\right]^{3+}$. The rotation was determined at the same wavelength for all three complexes.

The detailed publication containing an explanation of this principle, although announced by Werner, unfortunately never appeared. Despite this the above method has been applied successfully. For example, Brandt et al., [51] related the configurations of different tris (ortho-phenanthroline) complexes by means of resolution with $d$-antimonyl tartrate. Mäusen showed that enantiomers that formed the least soluble salts from the same reagent all demonstrated higher intraperitonale toxicity compared to their antipodes. Since the biological effect is probably closely associated with the stereochemistry of the compounds, this is an independent proof for the structural identity as proposed by Werner.

The value of this method lies principally in the relative ease with which a series of compounds can be compared to a compound of known configuration.

\section{Substitution Reactions on Optically Active Compounds}

Not all racemic compounds can be equally well resolved. Werner's observation that the optical activity is retained in many substitution reactions on complex ions of the general formula $\left[\mathrm{Co}(\mathrm{en})_{2} \mathrm{XY}\right]^{\mathrm{n}+}$ was therefore a valuable one. In addition, by the application of the above-mentioned solubility method, Werner was able to show

\section{Scheme 10.}

that no change in configuration occurred in these substitution reactions although in many cases the sign of the optical rotation was reversed. [37,52,53] Some examples are shown in Table 2.

More recent investigations ${ }^{54]}$ have shown that under certain conditions rearrangement reactions (Bailar rearrangements) occur in which the configuration is retained.
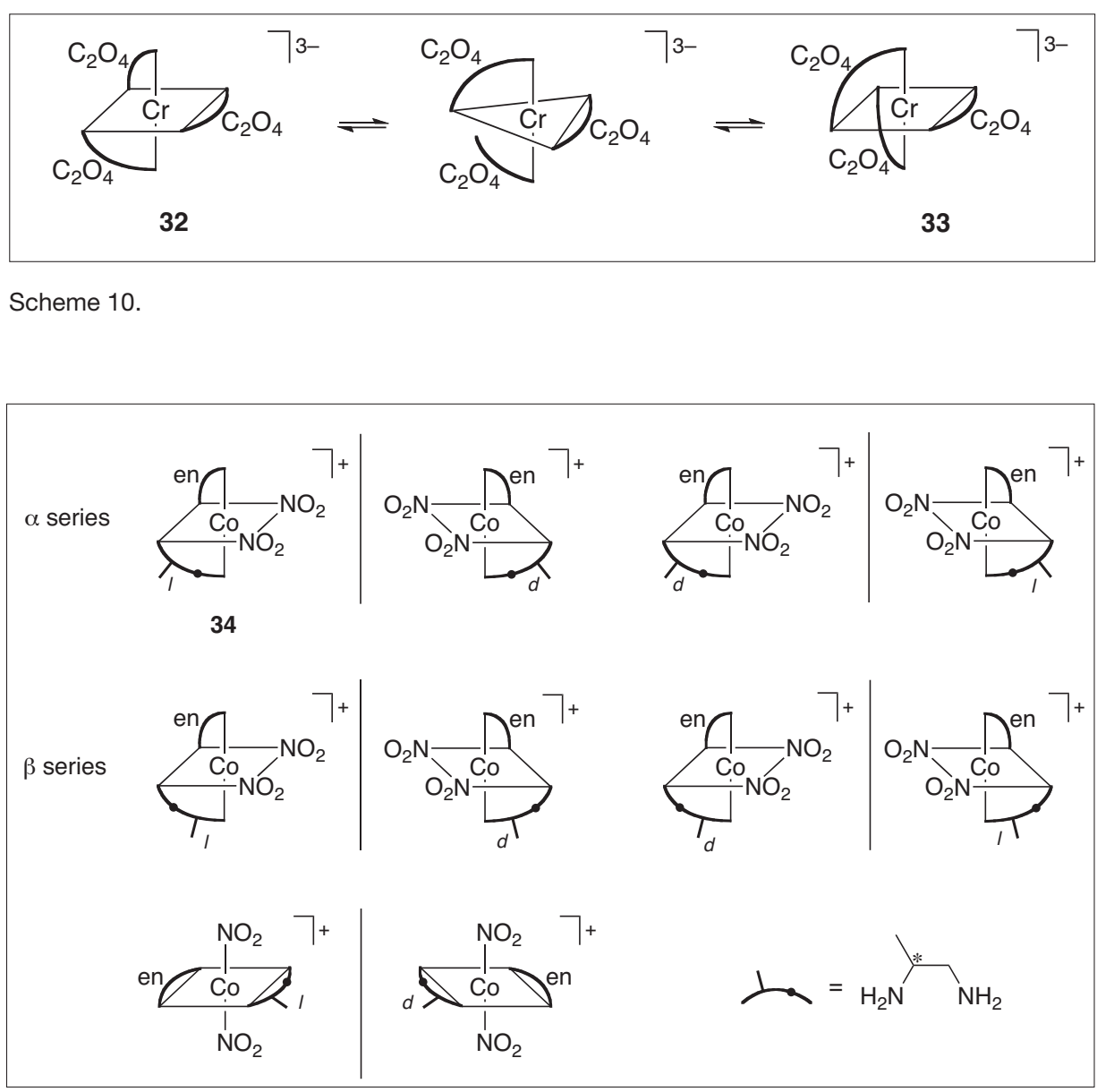

Fig. 13.

\section{Racemisation}

All the optically active complexes mentioned up to now are cationic. With the resolution of trioxalate chromate (III) salts (31), Werner demonstrated that also anions can be optically active; in addition this was the first nitrogen-free racemic mixture to be resolved. ${ }^{[55]}$

The behaviour of the enantiomers of 31 in solution is interesting: they racemise relatively quickly. Werner assumed that a bond is broken upon solution. The intermediate product can either revert to the starting product $\mathbf{3 2}$ or recombine to form 33 with a change of configuration (Scheme 10).

In a 1966 lecture, Bailar discussed different mechanisms for the racemisation of complexes with the general formula $\left[\mathrm{M}(\mathrm{AA})_{3}\right]$ and $\left[\mathrm{M}(\mathrm{AB})_{3}\right]$. One of these mechanisms that could not be excluded on the basis of existing research findings, corresponded exactly to Werner's mechanism described briefly here.[56]

\section{Optically Active Ligands}

Werner was not satisfied with solely the investigation of simple optically active complexes. This is demonstrated with an example here. Under Werner's supervision the stereoisomerism of the complex ion $\left[\mathrm{Co}(\mathrm{en})(\mathrm{pn})\left(\mathrm{NO}_{2}\right)_{2}\right]^{+}(\mathbf{3 4})$ was investigated. ${ }^{57]}$ 
The presence of propylenediamine (pn) increased the number of potential isomers considerably, since this bidentate ligand can coordinate in two different ways $(\alpha-$ and $\beta$-series) and it is also optically active. This leads to the ten theoretical stereoisomers shown in Fig. 13.

It was possible to isolate all these stereoisomers (the $\alpha$ - and the $\beta$-series have different crystal morphologies). From the ORD curves of individual enantiomers in the publication and from specially prepared enantiomeric mixtures, Kuhn and Szabo ${ }^{[58]}$ were later able to draw some interesting theoretical conclusions.

\section{Stereochemistry of Complexes with the Coordination Number 4}

Werner's few investigations into this class of materials were limited mainly to complexes of platinum(II). Two isomer series of complexes with the general formula $\left[\mathrm{PtA}_{2} \mathrm{X}_{2}\right]$ were known. Assuming that the compounds are symmetrically constructed, only planar or pyrimidal structures are possible (Fig. 14).

Werner ${ }^{[18]}$ only discussed the planar arrangement (35). Confirmation that this was correct came from the observation that the complex $\left[\mathrm{Pt}\left(\mathrm{NH}_{3}\right)_{4}\right] \mathrm{X}_{2}$ (37) could be oxidized with halogens to increase the coordination number of the central atom to form $\left[\mathrm{Pt}\left(\mathrm{NH}_{3}\right)_{4} \mathrm{X}_{2}\right] \mathrm{X}_{2}$ (38) (Scheme 11).

Platinum(II) complexes are indeed planar; this also applies to complexes of palladium(II), gold(III) etc. In other cases tetrahedral arrangement of the four ligands has been observed, for example in manganese(II) complexes.

\section{Determination of the Configura- tion of Isomeric Dichlorodiammine Platinum(II) Complexes}

Two isomers with the formula $\left[\mathrm{Pt}\left(\mathrm{NH}_{3}\right)_{2} \mathrm{Cl}_{2}\right]$ were known; platosammine chloride (39) and platosemidiammine chloride (40). Jørgensen ${ }^{[59]}$ assigned the following formulae to them (Fig. 15 left).

Using the experimental results from Jørgensen, [59] Werner was able to assign the correct structures of the two isomers already in $1893^{[18]}$ (Fig. 15 right).

Fig. 16 shows a summary of the most important arguments that enabled Werner to make his assignments. This assignment of configuration is a good example of the care that Werner took in his own research and in assessing that of other chemists and how he was able to apply logical reasoning to come to important conclusions.

\section{The Significance of Werner's Stereochemistry Research}

"The inorganic metal complexes form a special chapter in the development of stereochemistry. This chapter is entirely the shining creation of one single chem-

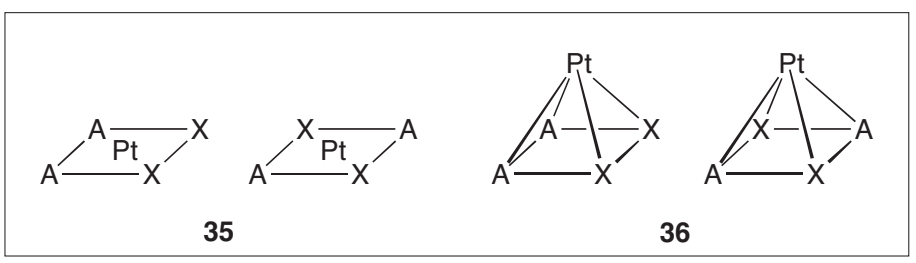

Fig. 14.

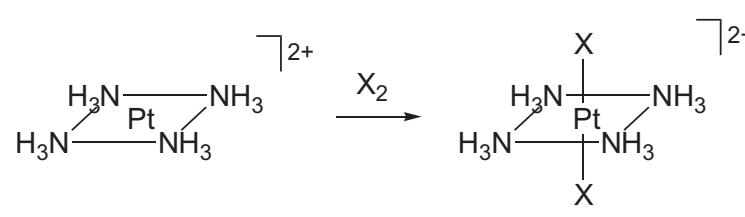

37

38

Scheme 11.

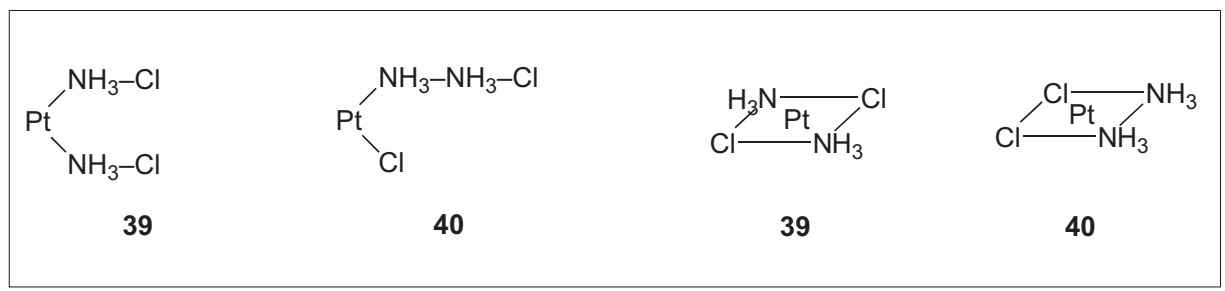

Fig. 15.

Determination of the configuration in compounds of the formula $\left[\mathrm{PtA}_{2} \mathrm{Cl}_{2}\right]$.

Known:

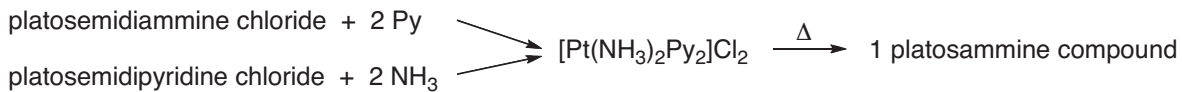

platosammine chloride $+2 \mathrm{Py}$

platopyridine chloride $+2 \mathrm{NH}_{3}$

$\left[\mathrm{Pt}\left(\mathrm{NH}_{3}\right)_{2} \mathrm{Py}_{2}\right] \mathrm{Cl}_{2} \stackrel{\Delta}{\longrightarrow} 2$ platosammine compounds

Assumption 1:

Assumption 2:

Fig. 16. 


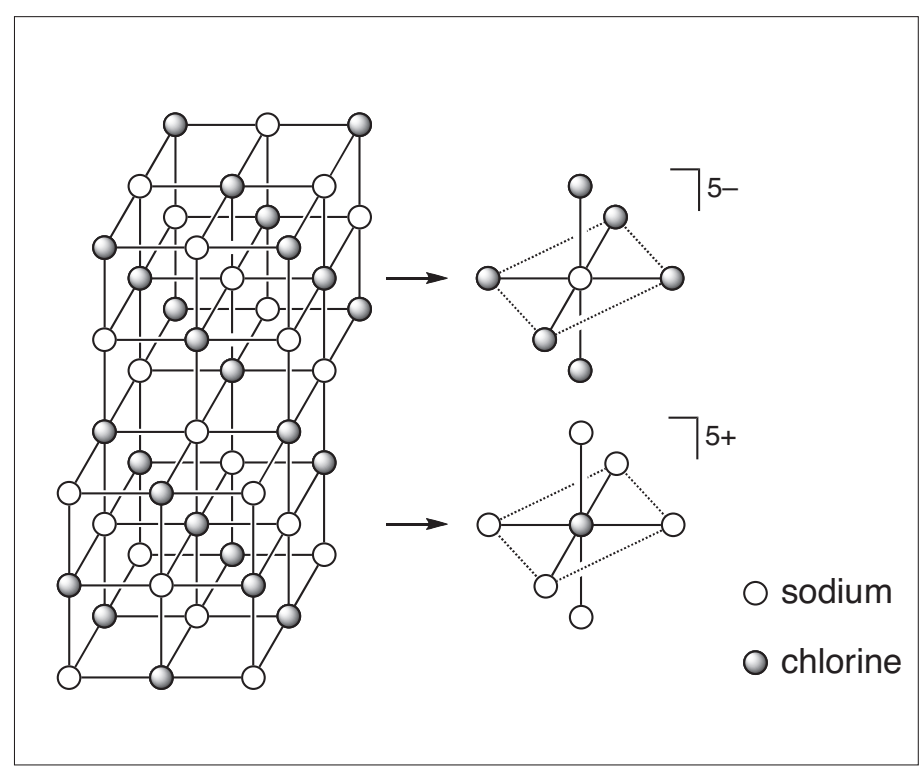

Fig. 17.
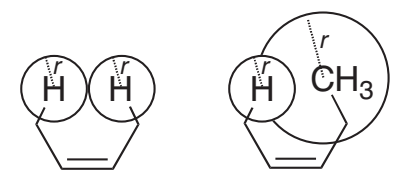

\section{$r=$ van der}

Waals radii

\section{"unhindered" "hindered" \\ cis double bond}

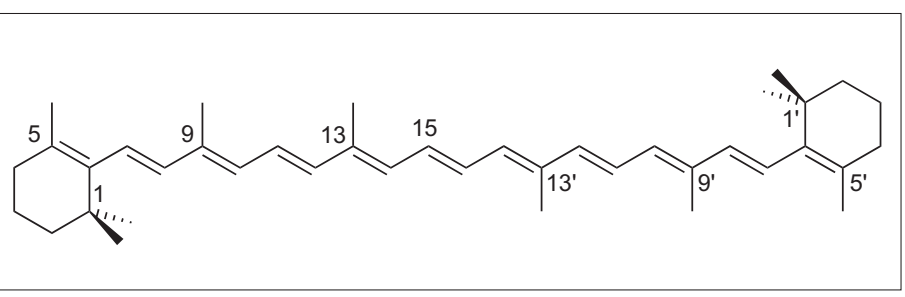

Fig. 19. ist, who combined genius with admirable logical thinking continually to develop and use his own experiments to test and confirm his theories. The long sought after bridge between organic and inorganic has been built; the frequently discussed differences between the two have been put aside. Alfred Werner must now be considered the equal to the two great chemists J. H. van't Hoff and Le Bel."

It is not necessary to expand upon P. Walden's words. ${ }^{[60]}$ What should be noted is that for a period of almost twenty years, the most important research on the stereochemistry of complexes came almost exclusively from Werner's laboratory. We should not forget that Werner, together with his mentor A. Hantzsch, founded the field of the stereochemistry of nitrogen compounds in $1890 .{ }^{[61]}$ At that time Werner was still employed at the ETH.

\section{Vindication of Werner's Theories}

The X-ray study of complexes with coordination numbers 4 and 6, ${ }^{[62-64]}$ carried out shortly after Werner's death, completely vindicated his coordination theory. However, the award of the Nobel Prize in 1913 shows that Werner's contempories were already convinced of its veracity.

\section{Paul Pfeiffer}

\section{The Stereochemistry of \\ Chromium(III) Complexes}

Up to now, the description of Werner's work on complexes with the coordination number 6 has relied heavily on the cobalt(III) complexes. Werner did in fact concentrate on these compounds, although he already had spoken in 1893 about similarities in complexes of chromium(III), platinum(IV),
rhodium(III), etc. ${ }^{[18]}$ Pfeiffer's achievement was that he tested and confirmed Werner's results on the complex- and stereochemistry of cobalt(III) by means of chromium(III) complexes, although Werner had apparently tried to dissuade him: "because these complexes are much too instable" (R. Wizinger $\left.{ }^{[65]}\right)$.

Pfeiffer's experiments will not be described here since their value lies not in their originality but rather in the additional support for Werner's octahedral theory.

\section{Crystal Structure and Coordination Theory}

In 1915 Pfeiffer pointed out that the information on the three-dimensional structure of crystals, as determined by M. von Laue and coworkers and W. L. and W. H. Bragg, could also be used to confirm Werner's coordination theory. ${ }^{[66]} \mathrm{He}$ was supported in this view shortly afterward by the Zurcher crystallographer P. Niggli. ${ }^{[67]}$ According to W. L. Bragg, in a sodium chloride crystal lattice the sodium and chlorine atom are located alternately in the corners of a cube. ${ }^{[68]}$ Pfeiffer pointed out that the chlorine atoms (or ions, as they would be referred to today) were surrounded by an octahedron of sodium atoms and vice versa for the sodium atoms. ${ }^{[69]}$ Fig. 17 illustrates this concept.

In a further publication, Pfeiffer discussed the coordination numbers 8 and 12 , also based on crystallographic studies. ${ }^{[70]}$

The connection between inorganic stereochemistry and crystallography, as Pfeiffer originally demonstrated, has gained continually in significance since then.

\section{Paul Karrer}

\section{Carotenoids with Hindered cis- Double Bonds}

Carotenoids contain, as a rule, seven to fifteen conjugated double bonds, most frequently ten or eleven. All-trans-compounds are more stable than the corresponding cisisomers. In an article published in 1939, L. Pauling[71] differentiated between unhindered and hindered cis-double bonds in carotenoids (Fig. 18).

The repulsion between the hydrogen atom and the methyl group is so large in compounds with hindered cis-double bonds that, according to Pauling, these should not exist. In $\beta$-carotene (41) therefore only the trans-double bonds in positions $9,13,15$, 13 ' and 9' should be able to be converted to the cis-double bond (Fig. 19).

Pauling's proposal became widely accepted as a fixed rule. In 1948 Karrer et al. ${ }^{[72]}$ produced evidence to the contrary: they reported the synthesis of cis,cis-3methylmuconic acid (42, Scheme 12),<smiles>COC(=O)C=CC(=O)OC(C)(C)C</smiles> 


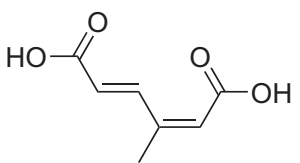

43

Fig. 20.

which contained a cis-double bond that was 'hindered' according to Pauling.

Thereafter Pauling revised his theory. ${ }^{[73]}$ He calculated that cis,cis-3-methylmuconic acid (42) should be $7.1 \mathrm{kcal} / \mathrm{mol}$ less stable than the trans,trans-isomer and therefore could exist, whereas the existence of carotenoids with hindered cis-double bonds would be extremely unlikely due to the loss of resonance energy.

The same opinion was shared somewhat later by Elvidge et al. In addition they pointed out that Karrer's cis,cis-3-methylmuconic acid (42) was in fact a cis,trans-3methylmuconic acid (43, Fig. 20) with an unhindered cis-double bond. [74]

Karrer and his coworkers put an end to the discussion by synthesizing compounds that contained without a doubt, Pauling's forbidden hindered cis-double bonds. They started with the observation that of the four isomers produced in the synthesis of 1,18-diphenyl-3,7,12,16-tetramethyloctadecanones, at least three contained a cis-double bond.[75] More careful investigation of the key reaction, the selective hydrogenation of two triple bonds in $\mathbf{4 4}$ (Scheme 13), showed that compound $\mathbf{4 5}$ with two hindered cis-double bonds was formed. ${ }^{[76]}$

The knowledge gained from these model compounds was substantiated shortly afterwards with the synthesis of cis-lycopenes with hindered double bonds by Garbers and Karrer.[77] In 1955 Karrer et al. even succeeded in the synthesis of a compound analogous to $\mathbf{4 5}$ which contained a much more sterically demanding phenyl group in place of the methyl. ${ }^{[78]} \mathrm{In}$ - dependent of the Karrer group, Oroshnik et al. prepared a further series of compounds, vitamin A analogues, that were also exceptions to Pauling's rule. [79]

The synthesis of compounds with hindered cis-double bonds by partial hydrogenation of triple bonds presented an elegant solution to the problem because direct transformation of trans-double bonds into hindered cis-double bonds has never been achieved. ${ }^{[80]}$

This example shows that even incorrect publications (the apparent synthesis of cis,cis-3-methylmuconic acid) can lead to progress in the field. It also shows that nature and the practical chemist can produce 'impossible' compounds to confound the theoreticians.

\section{The Configuration of Natural $\alpha$-Amino Acids}

Karrer's stereochemical research was carried out in close association with natural product chemistry, as seen in the previous section. This was confirmed by the investigations into configurational relationships in the natural $\alpha$-amino acids.

Karrer continued with the work done by L. Pasteur ${ }^{[81]}$ and E. Fischer and K. Raske. ${ }^{[82,83]}$ Karrer and his coworkers were able to prove the relationship of a whole series of amino acids to $l(-)$-serine (46, Fig. 21), which was used as a reference compound by the application of known chemical and physical methods. This work contributed much to support Karrer's proposal made in 1923 that all $\alpha$-amino acids of natural origin have the same configuration. ${ }^{[84]}$

In addition Karrer showed for the first time that alkaloids were also related to the $\alpha$-amino acids: the asymmetric centre in nicotine showed the same configuration as $l(-)$-serine. ${ }^{[85]}$

Knowledge of the configurational relationships among the individual natural $\alpha$-amino acids is significant for several reasons. It is necessary for bioenergetic investigations, for the study of enzyme action and enzyme metabolism, and in the investigation of the mode of action of<smiles>CC(C#CC=C(C)C=Cc1ccccc1)=CC=CC=C(C)C=Cc1ccccc1</smiles>

44 $\mathrm{H}_{2} / \mathrm{Pd}$ (poisoned)

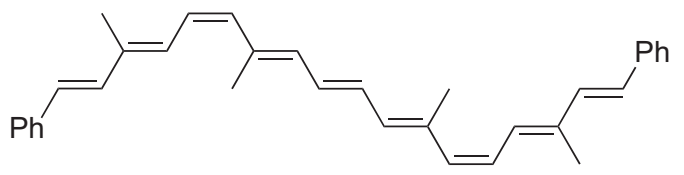

45

$$
\begin{aligned}
& \begin{array}{r}
\mathrm{CO}_{2} \mathrm{H} \\
\mathrm{H}_{2} \mathrm{~N}-\mathrm{C}-\mathrm{C}
\end{array} \\
& \mathrm{CH}_{2} \mathrm{OH} \\
& \begin{array}{r}
\mathrm{CO}_{2} \mathrm{H} \\
1 \\
\mathrm{H}_{2} \mathrm{~N}-\mathrm{C}-\mathrm{H} \\
1 \\
\mathrm{R}
\end{array} \\
& \text { I(-)-serine } \\
& \text { I-amino acid }
\end{aligned}
$$

Fig. 21.

antibiotics etc. ${ }^{[86]}$ Karrer's research in this field was more important as a contribution to the development of the field of natural product chemistry than to the development of stereochemistry but it is still worth a mention here.

\section{André S. Dreiding}

\section{The Application of Stereo Models}

The visualisation of steric relationships often causes problems even with relatively simple molecules. Not only the beginner has difficulty understanding projection- and stereo-formulae and picturing the three-dimensional structure of molecules. Models can help here. In many cases these consist of sticks and balls stuck together, sometimes even just a cork ball and four pins with different coloured heads, however, often a chemist will in general not be satisfied with such simple aids. In such cases, the chemist will often seek greater insight from a Dreiding stereomodel.

\section{The Stereo Model from Bretschneider}

According to Galinovsky et al., ${ }^{[87]}$ Bretschneider soldered together two pieces of wire, each bent in the middle, to form a tetrahedron. The individual carbon units were connected by means of springs. These models were suitable for the conformational analysis of hydrocarbon molecules.

\section{The Stereo Model from Dreiding}

In 1959 Dreiding announced a further development of Bretschneider's model.[88] The most significant improvement was based on the following knowledge: The length $d_{\mathrm{AB}}$ of a covalent bond between two atoms $\mathrm{A}$ and $\mathrm{B}$ can be divided into two so-called covalent bonding radii $r_{\mathrm{A}}$ and $\mathrm{r}_{\mathrm{B}}$. These covalent bonding radii are constant additive values (see for example E. S. Gould[89]). Dreiding incorporated this into his model. For the basic element he did not take the individual atoms, but rather their simplest hydrogen compounds (e.g. methane for tetrahedral carbon, ammonia for trivalent nitrogen, water for oxyether etc.). These basic elements consisted of, where possible, the same number of balls and sticks or tubes. The distance between 


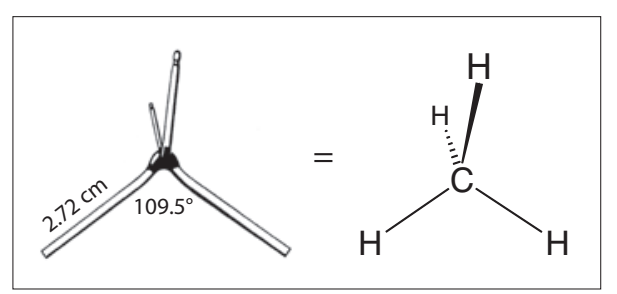

Fig. 22.

the mid point of one of these basic elements to the end of a stick or tube corresponds exactly to the bond length $\mathrm{X}-\mathrm{H}$ in the scale 1:0.4 $\times 10^{-8}$; the valence angle corresponds to the true observed value (Fig. 22).

Each tube has, measured from the endpoint, at the distance of two covalent hydrogen atom radii, a stopper. This ensures that when two elements are joined together the correct scaled bond length is attained (Fig. 23).

A press-stud type mechanism prevents the individual elements from falling apart.

In the meantime the Dreiding stereo model has become widely distributed. Therefore a further description is unnecessary. It is the best known of all the currently available models. It is particularly simple to use (cyclohexane can be constructed in six steps whereas other models need 18) and it is exact. Its many applications will be described in the next section.

\section{Applications of Dreiding Models}

It is not possible to describe the full range of applications that the Dreiding models can be used for. Therefore a summary of uses from the brochure from the W. Buechi ${ }^{[90]}$ company who produce and sell the models is given. (Some examples are also given in Fig. 24.) for.

Dreiding Stereo models can be used

- Stereochemical analysis

- Isomeric analysis

- Symmetry deductions

- Conformation analysis (energetic studies)

- Analysis of dynamic reactions

- Study of reaction mechanisms by visualization of the transition state

- Investigation of steric hindrance

- Analysis of stereospecific reactions controlled by orbital symmetry

- Interpretation of coupling constants and magnetic field effects in NMR

- Analysis of chirality rules in optical rotation dispersion and circular dichroism

- Chirality and helicity determinations

This list demonstrates how extensive the applications of Dreiding models are and therefore by association also stereochemistry.

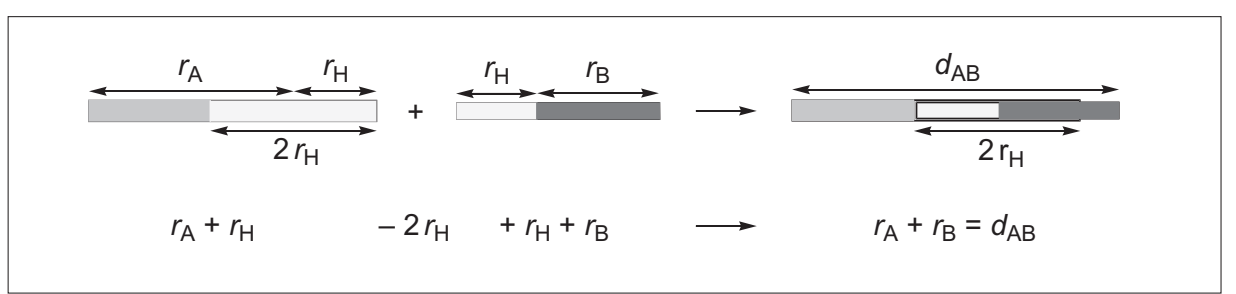

Fig. 23.

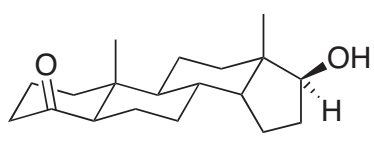

5-epiandrostan-3-on-17-ol

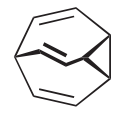

bullvalene

Fig. 24.

\section{The Stereo Model from Fieser}

The Dreiding stereo model is too small for use in teaching and it is relatively expensive. L. F. Fieser provided a solution in 1963 by adapting Dreiding's America patent from 1961 to produce a larger and cheaper version in plastic. ${ }^{\text {[91-93] }}$ These models do not have the precision and manipulability of the Dreiding models and some elements do break relatively easily. However, they are more suitable for wider use in universities and schools and should eventually replace the simple ball and stick models.

\section{Short Biographical Details of the Chemists Mentioned here}

\section{Johannes Wislicenus}

Johannes Wislicenus was born in 1835 in Thuringia. He studied chemistry in $\mathrm{Zu}-$ rich under the supervision of Städler. He became associate professor in 1864 and was full professor at the university from 1867 to 1870 . He later moved to the Universities of Würzburg and Leipzig. He died in 1902.

\section{Alfred Werner}

Alfred Werner was born in Mulhouse in 1866. He studied chemistry in Zurich and, after spending one year in Paris, became associate professor at the age of 27 as the successor to Viktor Merz. He was promoted to full professor two years later and remained in this position until shortly before his death in 1919. He was awarded the Nobel Prize for Chemistry in 1913.

\section{Paul Pfeiffer}

Paul Pfeiffer was born in Elberfeld in 1875. He completed his dissertation under the supervision of Werner in 1898, and after postdoctoral studies in Leipzig and Würzburg worked as associate professor until he left Zurich in 1916. Via Rostock (1916) and Karlsruhe (1919) he eventu- ally took up a position at the University of Bonn in 1922. He retired in 1947 and died on 4. March 1951.

\section{Paul Karrer}

Karrer was born on 2. April 1889 in Moscow to Swiss parents. He began his studies in chemistry at the University of Zurich in 1908, in 1912 he became an assistant to P. Ehrlich. In 1918 he was elected professor and one year later he became full professor of chemistry at the University. He remained in this position until 1959. In 1937 Karrer was awarded the Nobel prize for chemistry. He died in 1971.

\section{André S. Dreiding}

Dreiding was born on 22. June 1919 in Zurich. He studied in the USA, where he also worked as an assistant and a visiting professor. In 1954 he completed his habilitation at the University of Zurich and became lecturer. From 1962 to 1987 he was professor in chemistry at the University. At the age of 90 he continues to profess stereochemical philosophy from his home in Herrliberg, Switzerland.

\section{Acknowledgements}

I would like to thank Prof. Dr. P. Karrer for a list of his most important stereochemistry articles, W. Buechi, the glass apparatus manufacturers in Flawil, for permission to use illustrations from the Dreiding Stereo model brochure and one of my fellow students for proof-reading the manuscript.

Received: Originally submitted 1968

[1] V. Meyer, Ber. deutsch. chem. Ges. 1890, 23, 567.

[2] W. H. Wollaston, Phil. Trans. Royal Soc. (London) 1808, 96.

[3] J. H. van't Hoff, 'Voorstel tot uitbreiding der tegenwoordig in de scheikunde gebruikte structuur-formules in de ruimte', Utrecht, $\mathbf{1 8 7 4}$.

[4] J. A. Le Bel, Bull. Soc. chim. Fr. 1874, 22, 337.

[5] A. Kekulé, Ber. deutsch. chem. Ges. 1869, 2, 548.

[6] O. Meister, Ber. deutsch. chem Ges. 1896, 2, 619. 
[7] J. Wislicenus, Liebigs Ann. Chem. 1863, 128, 1.

[8] J. Wislicenus, Liebigs Ann. Chem. 1873, 167, 302.

[9] J. H. van't Hoff, 'Die Lagerung der Atome im Raum', translated by F. Herrmann, Braunschweig, 1877.

[10] J. Wislicenus, 'Räumliche Anordnung der Atome in organischen Molekülen und ihre Bestimmung in geometrische-isomeren ungesättigten Verbindungen', Leipzig, 1887.

[11] C. W. Blomstrand, 'Chemie der Jetztzeit', Heidelberg, 1869.

[12] C. W. Blomstrand, Ber. deutsch. chem. Ges. 1871, 4, 40.

[13] S. M. Jørgensen, J. prakt. Chem. 1890, 41, 429.

[14] S. M. Jørgensen, J. prakt. Chem. 1883, 27, 433.

[15] A. S. Couper, C. r. hebd. Séances Acad. Sci. 1858, 46, 1157.

[16] A. Kekulé, Liebigs Ann. Chem. 1858, 106, 129.

[17] A. Werner, Vierteljahresschrift naturforsch. Ges. Zürich 1891, 36, 129.

[18] A. Werner, Z. anorg. Chem. 1893, 3, 267.

[19] A. Werner, A. Miolati, Z. physikal. Chem. 1893, 12,35 .

[20] A. Werner, A. Miolati, Z. physikal. Chem. 1894, 14, 506.

[21] A. Werner, A. Miolati, Z. physikal. Chem. 1896, $21,225$.

[22] L. Tschugaeff, N. Wladimiroff, C. r. hebd. Séances Acad. Sci. 1915, 160, 840.

[23] A. Werner, Z. anorg. Chem. 1895, 8, 153.

[24] G. A. Barday, B. F. Hoskins, J. Chem. Soc. 1962, 586.

[25] S. M. Jørgensen, Z. anorg. Chem. 1892, 2, 282.

[26] A. Werner, Ber. deutsch. chem. Ges. 1907, 40, 4817.

[27] A. Werner, Ber. deutsch. chem. Ges. 1911, 44, 873.

[28] S. M. Jørgensen, J. prakt. Chem. 1889, 39, 1.

[29] A. Werner, Liebigs Ann. Chem. 1912, 386, 1.

[30] F. Basolo, in 'The Chemistry of the Coordination Compounds', Ed. J. C. Bailar, Jr., New York and London, 1956, p. 280.

[31] E. Fischer, Liebigs Ann. Chem. 1911, 381, 123.

[32] P. Pfeiffer, Liebigs Ann. Chem. 1911, 383, 92.

[33] A. Werner, A. Vilmos, Z. anorg. Chem. 1899, 21, 145.

[34] L. Pasteur, Ann. Chim. Phys. 1848, 24, 442.

[35] A. Werner, Ber. deutsch. chem. Ges. 1911, 44, 1887.

[36] A. Werner, Ber. deutsch. chem. Ges. 1911, 44, 2445.

[37] A. Werner, Ber. deutsch. chem. Ges. 1911, 44, 3272.

[38] A. Werner, Ber. deutsch. chem. Ges. 1911, 44, 3279 .
[39] A. Werner, Ber. deutsch. chem. Ges. 1912, 45, 121

[40] A. Werner, Ber. deutsch. chem. Ges. 1913, 46 3674.

[41] A. Werner, Ber. deutsch. chem. Ges. 1914, 47, 3087.

[42] A. Werner, Ber. deutsch. chem. Ges. 1907, 40, 15.

[43] A. Werner, Ber. deutsch. chem. Ges. 1911, 44, 3132.

[44] A. Werner, Ber. deutsch. chem. Ges. 1912, 45 433

[45] A. Werner, Ber. deutsch. chem. Ges. 1912, 45, 1228 .

[46] A. Werner, Vierteljahresschrift naturforsch Ges. Zürich 1917, 62, 553.

[47] A. Werner, P. Smirnoff, Helv. Chim. Acta 1920 $3,472$.

[48] M. Délepine, C. r. hebd. Séances Acad. Sci. $\mathbf{1 9 1 4}, 159,239$

[49] A. Werner, Ber. deutsch. chem. Ges. 1913, 46, 3229.

[50] R. D. Gillard, 'Progress in Inorganic Chemistry' Ed. F. A. Cotton, New York, London, Sidney, 1966, 7, 233.

[51] W. W. Brandt, F. P. Dwyer, E. C. Gyarfas, Chem. Revs. 1954, 54, 998.

[52] A. Werner, M. Cutcheon, Ber. deutsch. chem. Ges. 1912, 45, 3281.

[53] A. Werner, Bull. Soc. Chim. France 1912, 11, 1.

[54] J. C. Bailar, Jr., R. W. Auten, J. Amer. Chem. Soc. 1934, 56, 774.

[55] A. Werner, Ber. deutsch. chem. Ges. 1912, 45 3061.

[56] J. C. Bailar, Helv. Chim. Acta (Fasciculus extraordinarius Alfred Werner) 1967, 82

[57] A. Werner, Helv. Chim. Acta 1918, 1, 5.

[58] W. Kuhn, A. Szabo, Z. physikal. Chem. 1932, $15 B, 59$.

[59] S. M. Jørgensen, J. prakt. Chem. 1886, 33, 489.

[60] P. Walden, Naturwiss. 1925, 16, 333.

[61] A. Hantsch, A. Werner, Ber. deutsch. chem. Ges. 1890, 23, 11 .

[62] R. W. G. Wychoff, E. Posnjak, J. Amer. Chem. Soc. 1921, 43, 2292.

[63] P. Scherrer, P. Stoll, Z. anorg. Chem. 1922, 121, 319.

[64] R. G. Dickinson, J. Amer. Chem. Soc. 1922, 44 , 276 and 2404.

[65] R. Wizinger, Angew. Chem. 1950, 62, 201.

[66] P. Pfeiffer, Z. anorg. Chem. 1915, 92, 376.

[67] P. Niggli, Z. anorg. Chem. 1916, 94, 207.

[68] W. L. Bragg, Z. anorg. Chem. 1915, 90, 185 and 246.

[69] P. Pfeiffer, Z. anorg. Chem. 1916, 97, 161.

[70] P. Pfeiffer, Z. anorg. Chem. 1918, 105, 26.
[71] L. Pauling, Fortschr. Chem. Org. Naturstoffe 1939, 3, 203.

[72] P. Karrer, R. Schwyzer, A. Neuwirth, Helv Chim. Acta 1948, 31, 1210 .

[73] L. Pauling, Helv. Chim. Acta 1949, 32, 2241.

[74] J. A. Elvidge, R. P. Linstead, P. Sims, J. Chem. Soc. 1951, 3398

[75] C. H. Eugster, C. F. Garbers, P. Karrer, Helv. Chim. Acta 1952, 35, 1179

[76] C. F. Garbers, C. H. Eugster, P. Karrer, Helv. Chim. Acta 1952, 35, 1850

[77] C. F. Garbers, P. Karrer, Helv. Chim. Acta 1953 $36,828$.

[78] H. H. v. Ziegler, C. H. Eugster, P. Karrer, Helv Chim. Acta 1955, 38, 613.

[79] W. Orosnik, G. Karmas, A. D. Mebane, J. Amer. Chem. Soc. 1952, 74, 295.

[80] Since Hermann wrote this article in 1968, this synthetic problem has been resolved.

81] L. Pasteur, Ann. Chim. Phys. 1851, 31, 81.

[82] E. Fischer, K. Raske, Ber. deutsch. chem. Ges. 1907, 40, 3717

[83] E. Fischer, K. Raske, Ber. deutsch. chem. Ges. 1908, 41, 893 .

[84] P. Karrer, Helv. Chim. Acta 1923, 6, 957.

[85] P. Karrer, R. Widmer, Helv. Chim. Acta 1925, 8, 364.

[86] J. P. Greenstein, M. Winitz, 'Chemistry of the Amino Acids', New York, London, 1961, p. 446.

[87] F. Galinovsky, J. Derkosch, H. Nesvadba, P. Meomdl, K. H. Orgler, Mh. Chem. 1957, 88 , 967.

[88] A. S. Dreiding, Helv. Chim. Acta 1959, 42, 1339

[89] E. S. Gould, 'Mechanismus und Struktur in der organischen Chemie', Weinheim, 1962, p. 49.

[90] 'Dreiding - Stereo models', Ed. 3, Flawil, 1967.

[91] L. F. Fieser, J. Chem. Ed. 1963, 40, 62.

[92] L. F. Fieser, J. Chem. Ed. 1963, 40, 457.

[93] L. F. Fieser, J. Chem. Ed. 1965, 42, 408

The references given below are not explicitly mentioned in the text. They were, however, a very valuable aid in preparing this article.

P. Karrer, 'Alfred Werner', Helv. Chim. Acta 1920, 3, 196.

G. Schwarzenbach, 'Alfred Werner and his accomplishments', Helv. Chim. Acta (Fasciculus extraordinarius Alfred Werner) 1967, 38.

'The Chemistry of the Coordination Compounds', Ed. J. C. Bailar, Jr., New York, London, 1956. 